\section{АНАЛІЗ ДИНАМІКИ ОСНОВНИХ ПОКАЗНИКІВ MOHETAPHOÏ ПОЛІТИКИ В УКРАЇНI}

\author{
ПЕТИК Л.О., \\ кандидат економічних наук, \\ доцент кафедри фінансового менеджменту
}

БАЦМАН І.В., студентка факультету управління фінансами та бізнесу БІДА М.С.,
студентка
факультету управління фінансами та бізнесу,
Львівський національний університет
імені Івана Франка
(м. Львів)

У статті розкрито сутність поняття грошово-кредитної політики, проаналізовано ї̈ дефініцію різними науковцями та вченими, і визначено, щзо монетарна політика є базовою складовою фінансової політики держави, що спрямовується на стабільне забезпечення національної економіки грошовою масою у потрібній кількості, посилення ефективності обігу готівки, акумуляції коштів економічних суб'єктів і їх залучення до банківської сфери, ефективне спрямування кредитних ресурсів на потреби сталого розвитку економіки України. Подано основні монетарні показники, щзо характеризують стан грошового обігу, до яких належать: пропозиція грошей (грошова маса), облікова ставка, індекс інфлячії та валютний курс. Досліджено динаміку зміни грошової маси в Украйні. Визначено кількість грошових агрегатів, до яких належать: М0 (готівкові кошти в обігу поза банком), М1 (М0 й переказні депозити в національній валюті), M2 (M1 і переказні депозити в іноземній валюті й інші депозити), M3 (М2 й иінні папери, окрім акиій), щэо діють в Україні, та їх характеристика. Визначено сутність поняття облікової ставки й зазначено ї̈ вплив на вартість кредитів, які Національний Банк України надає комериійним банкам, що змінює попит населення на отримання споживчого кредиту. Також проаналізовано динаміку облікової ставки Національного Банку України за 2014-2021 роки. Визначено поняття інфляиії, а також розглянуто індекс споживчих иін на кінець кожного з періодів 2014-2020 років і проаналізовано динаміку індексу інфляції: причини стрімкого розвитку інфлячійних прочесів у 2014-2015 роках, зниження темпів у 2017-2020 роках $i$ зазначено прогнозні показники інфляиії на кінецьь 2021-2022 років. Проведено аналіз середнього курсу обміну валют (гривня до долара США) у банках Украйни за період 2014-2021 років $i$ визначено наслідки різкого коливання валютних курсів, щзо сприяють утраті українцями значної частини валютних заощаджень. У статті запропоновано заходи для захисту заощаджень громадян від підвищення курсів валют щодо гривні: збереження валютних цінностей у банках $i$ страхування їх від зниження курсів валют.

Ключові слова: монетарна політика, основні показники монетарної політики, грошова маса, інфляція, валютний курс, облікова ставка.

Табл.: 3. Рис.: 3. Літ.: 17. 


\title{
ANALYSIS OF THE DYNAMICS OF THE MAIN INDICATORS OF MONETARY POLICY IN UKRAINE
}

\author{
PETYK LUBOV, \\ Candidate of Economic Sciences, Associate Professor \\ of the Department of Financial Management
}

BATSMAN IRYNA,

Student

of the Faculty of Financial Management and Business

\author{
BIDA MARTA, \\ Student \\ of the Faculty of Financial Management and Business \\ Ivan Franko National University of Lviv
}

(Lviv)

The article reveals the essence of the concept of monetary policy, analyzes its definition by various scientists and scholars, and determines that monetary policy is a basic component of financial policy of the state, aimed at stable provision of the national economy with the right amount of money, increasing cash efficiency, accumulation funds of economic entities and their involvement in the banking sector, effective allocation of credit resources for the needs of sustainable development of Ukraine's economy. The main monetary indicators that characterize the state of money circulation are presented, they include: money supply (money value), discount rate, inflation index and exchange rate. The dynamics of money supply change in Ukraine is studied. The number of monetary aggregates is determined, which include: MO (cash in circulation outside the bank), M1 (MO and transferable deposits in national currency), M2 (M1 and transferable deposits in foreign currency and other deposits), M3 (M2 and securities except for shares) operating in Ukraine, and their characteristics. The essence of the concept of discount rate is determined and its influence on the cost of loans provided by the National Bank of Ukraine to commercial banks, which changes the demand of the population for a consumer loan. The dynamics of the discount rate of the National Bank of Ukraine for 2014-2021 is also analyzed. The concept of inflation is defined, the consumer price index at the end of each period of 2014-2020 is considered and the dynamics of the inflation index is analyzed: the reasons for the rapid development of inflation in 2014-2015, declining rates in 2017-2020 and the forecast inflation at the end 2021-2022 are shown. The analysis of the average exchange rate (against the US dollar) in the banks of Ukraine for the period 2014-2021 is conducted and the consequences of sharp fluctuations in exchange rates, which contribute to the loss by Ukrainians a significant part of foreign currency savings are determined. The article proposes measures to protect citizens' savings from the appreciation of exchange rates against the hryvnia: preservation of currency values in banks and insuring them against depreciation of exchange rates.

Key words: monetary policy, main indicators of monetary policy, money supply, inflation, exchange rate, discount rate.

Tabl.: 3. Fig.: 3. Ref.: 17. 


\title{
АНАЛИЗ ДИНАМИКИ ОСНОВНЫХ ПОКАЗАТЕЛЕЙ МОНЕТАРНОЙ ПОЛИТИКИ В УКРАИНЕ
}

\author{
ПЕТИК Л.О., \\ кандидат экономических наук, \\ доцент кафедры финансового менеджсмента
}

\author{
БАЦМАН И.В., \\ студентка \\ факультета управления финансами и бизнеса
}

(2. Львов)

\begin{abstract}
B cтатье раскрыта сущность понятия денежно-кредитной политики, проанализирована ее дефиниция разными учеными, и определено, что монетарная политика является базовой составляющей финансовой политики государства, которая направляется на стабильное обеспечение начиональной экономики денежной массой в нужном количестве, усиление эфррективности обращчения наличных, аккумулящии средств экономических субъектов и их вовлечение в банковскую сферу, эффективное направление кредитных ресурсов на потребности устойчивого развития экономики Украины. Представлены основные монетарные показатели, характеризующие состояние денежного обращения. К ним относятся: предложение денег (денежная масса), учетная ставка, индекс инфляции и валютный курс. Исследована динамика изменения денежной массы в Украине. Определено количество денежных агрегатов, $\kappa$ которым относятся: Мо (наличные средства в обращении вне банка), M1 (М0 и переводные депозиты в национальной валюте), M2 (M1 и переводные депозиты в иностранной валюте и другие депозиты), М3 (М2 и иеннье бумаги, кроме акций), действующих в Украине, и их характеристика. Определена сущность понятия учетной ставки и отмечено ее влияние на стоимость кредитов, которые Национальный Банк Украины предоставляет коммерческим банкам, что изменяет спрос населения на получение потребительского кредита. Также проанализирована динамика учетной ставки Национального Банка Украины за 2014-2021 годы. Определено понятие инфляции, также рассмотрен индекс потребительских иен на конеи каждого из периодов 2014-2020 годов и проанализирована динамика индекса инфляции: причины стремительного развития инфляционных процессов в 2014-2015 годах, снижение темпов в 2017-2020 годах и указаны прогнозные показатели инфляции на конеи 2021-2022 годов. Проведен анализ среднего курса обмена валют (к доллару США) в банках Украины за период 2014-2021 годов и определены последствия резкого колебания валютных курсов, способствуюшие потере украинщами значительной части валютных сбережений. $B$ статье предложены меры по защите сбережений граждан от повышения курсов валют по отношению к гривне: сохранение валютных ценностей в банках и страхование их от снижения курсов валют.
\end{abstract}

Ключевые слова: монетарная политика, основные показатели монетарной политики, денежная масса, инфляция, валютный курс, учетная ставка.

Табл.: 3. Рис.: 3. Лит.: 17. 
Постановка проблеми. На сучасному етапі розвитку України, яка характеризується нестабільною політичною та економічною ситуацією, існує проблема у проведенні заходів стабілізації грошової системи й кредитування, що $є$ основою монетарної політики. Для їі ефективного проведення держава повинна звернути увагу на динаміку монетарних показників.

Аналіз останніх досліджень і публікацій. Аналізом динаміки зміни монетарних показників i дослідженням їх впливу на економіку країни займалися такі відомі вітчизняні науковці як: Бондаренко Л., Будаговська С., Бурда М., Виплош Ч., Сомик А. та інші.

Монетарні показники складають основу для проведення заходів монетарної політики, тому, незважаючи на численні напрацювання, актуальним $\epsilon$ аналіз динаміки основних показників грошово-кредитної політики, що мають безпосередній вплив на економіку країни.

Формулювання цілей статті. Головною метою статті $є$ дослідження монетарних показників в Україні, причин їх зміни й вплив на національну економіку.

Виклад основного матеріалу дослідження. Монетарній політиці належить важлива роль у досягненні економічного розвитку України, причиною цьому слугують сучасні економічні умови, що характеризуються активізацією трансформаційних процесів.

Дефініція поняття грошово-кредитної політики є досить широкою, тому різні науковці трактують iї неоднаково. Для кращого розуміння суті пропонуємо розглянути кілька визначень (табл. 1).

Табличяя 1

Трактування поняття «монетарна політика» різними вченими

\begin{tabular}{|c|c|}
\hline Дослідник & Визначення \\
\hline Бондаренко Л. & $\begin{array}{l}\text { Сукупність заходів у сфері грошового обігу й кредитних відносин, які проводить } \\
\text { держава. }\end{array}$ \\
\hline Сомик А. & $\begin{array}{l}\text { Курс держави у сфері забезпечення ії економічної безпеки методами грошово- } \\
\text { кредитного регулювання, що визначається у сукупності заходів грошово- } \\
\text { кредитного характеру. }\end{array}$ \\
\hline Будаговська С. & $\begin{array}{l}\text { Політика, яка впливає на обсяг і структуру виробництва, загальний рівень цін, } \\
\text { інвестицій та зайнятості, на стан зовнішньоекономічної рівноваги, змінюючи } \\
\text { пропозицію грошей в економіці. }\end{array}$ \\
\hline Бурда М., Виплош Ч. & $\begin{array}{l}\text { Один із альтернативних видів політики уряду, що спрямовується на вплив на } \\
\text { процентні ставки й валютні курси, загальніше - на умови фінансових ринків і } \\
\text { їхні зв'язки з реальною економікою. }\end{array}$ \\
\hline Плужников I. & $\begin{array}{l}\text { Системна сукупність національних інтересів (пріоритетів), наукових підходів і } \\
\text { заходів у сфері грошового обігу й кредиту, направлених на регулювання і } \\
\text { забезпечення економічного зростання, стабільності грошової одиниці України, } \\
\text { соціального захисту населення, стримування інфляції та вирівнювання } \\
\text { платіжного балансу країни. }\end{array}$ \\
\hline Коваленко В. & $\begin{array}{l}\text { Системний, організаційно оформлений регулятивний механізм зі своїми } \\
\text { специфічними цілями, інструментами й роллю в економічній системі. } \\
\text { Об'єктами, на які спрямовуються регулятивні заходи грошово-кредитної } \\
\text { політики, є: пропозиція грошей; процентна ставка; валютний курс; швидкість } \\
\text { грошового обігу; рівень інфляції. }\end{array}$ \\
\hline Юхименко П. & $\begin{array}{l}\text { Частина економічної політики держави, сукупність законодавчих і нормативних } \\
\text { актів, бюджетно-податкових й інших монетарних інструментів інститутів і } \\
\text { заходів державної влади, які, згідно із законодавством, мають повноваження } \\
\text { щодо формування та використання фінансових ресурсів держави й регулюють } \\
\text { фінансово-кредитні потоки у сферах економіки відповідно до стратегічних і } \\
\text { тактичних цілей державної економічної політики. }\end{array}$ \\
\hline
\end{tabular}

Джерело: сформовано авторами на основі [1, с. 73; 2, с. 171] 


\section{EФМ}

http://efm.vsau.org/

Деякі науковці розглядають грошово-кредитну політику в широкому розумінні, вважаючи, що вона охоплює кілька аспектів економічної діяльності. Цілком слушною є позиція С.М. Дячека, який зазначає, що деякі науковці $\epsilon$ прихильниками широкого підходу, за якого до монетарної політики належить комплекс заходів держави у грошовій сфері, зокрема й ті, що здійснюються за участю й без участі центрального банку, а саме: регулювання економічного зростання; стримування інфляції; забезпечення стабільності грошової одиниці; забезпечення зайнятості населення; вирівнювання платіжного балансу; підвищення ліквідності й кредитоспроможності банківських інститутів; забезпечення соціального захисту населення тощо [2, с. 172].

Згідно із Законом України «Про Національний банк України», грошовокредитна політика - це комплекс заходів у сфері грошового обігу й кредиту, спрямованих на забезпечення стабільності грошової одиниці України через використання визначених законом засобів та методів [3].

Отож, можна зазначити, що монетарна політика - це сукупність заходів, що виконує держава, які спрямовані на досягнення визначених стратегічних цілей економічного розвитку країни. Такі цілі монетарної політики можуть бути орієнтовані на $[4$, с. 5]:

1) підтримання низьких темпів інфляції, що $є$ обов'язковою умовою підтримання макроекономічної рівноваги в економіці й стану визначеності для всіх економічних агентів, оскільки стійкість грошової одиниці забезпечує можливості для довгострокових заощаджень й інвестицій;

2) забезпечення стабільності національної валюти в плані курсового співвідношення з іншими валютами, що є обов'язковою умовою підтримання довіри до неї з боку національного та іноземного бізнесу, а також полегшення умов праці суб'єктів зовнішньоекономічної діяльності, що визначається можливостями іiі кращого планування на тривалу перспективу та укладення довгострокових контрактів;

3) забезпечення зовнішньоекономічної рівноваги - підтримання рівноваги платіжного балансу, оскільки діяльність суб'єктів господарювання на зовнішніх ринках, збалансування грошових i товарних потоків країни, як учасника світового ринку, є обов'язковою умовою стабільного економічного розвитку;

4) сприяння високому рівню зайнятості (наприклад, Федеральна Резервна Система у США) та ін.

Від правильного вибору інструментів грошово-кредитної політики, механізму їх упровадження залежить досягнення загальноекономічних цілей держави, рівноваги на грошово-кредитному ринку та забезпечення економічного зростання.

До переліку інструментів грошово-кредитної політики можемо віднести такі $[4$, с. 7]:

- політика визначення та регулювання норм обов'язкових резервів для комерційних банків;

- відсоткова політика;

- політика рефінансування комерційних банків;

- політика управління золотовалютними резервами;

- політика операцій на відкритому ринку (операції із цінними паперами, 
зокрема з казначейськими зобов'язаннями);

- політика управління валютним курсом;

- регулювання експорту й імпорту капіталу;

- емісія власних боргових зобов'язань й операції з ними.

До суб'єктів грошово-кредитної політики належать: Національний банк України, Кабінет Міністрів України, Верховна Рада України, установи зі страхування депозитів й інші. Визначальна роль у здійсненні грошовокредитного регулювання належить центральному банку, який, як правило, не підпорядковується органам виконавчої влади, що дозволяє йому проводити незалежну грошово-кредитну політику [5, с. 249].

Сутнісна характеристика грошово-кредитної політики розкривається через монетарні показники, що характеризують стан грошового обігу. Ознайомитися з основними із таких показників можна на рис. 1.

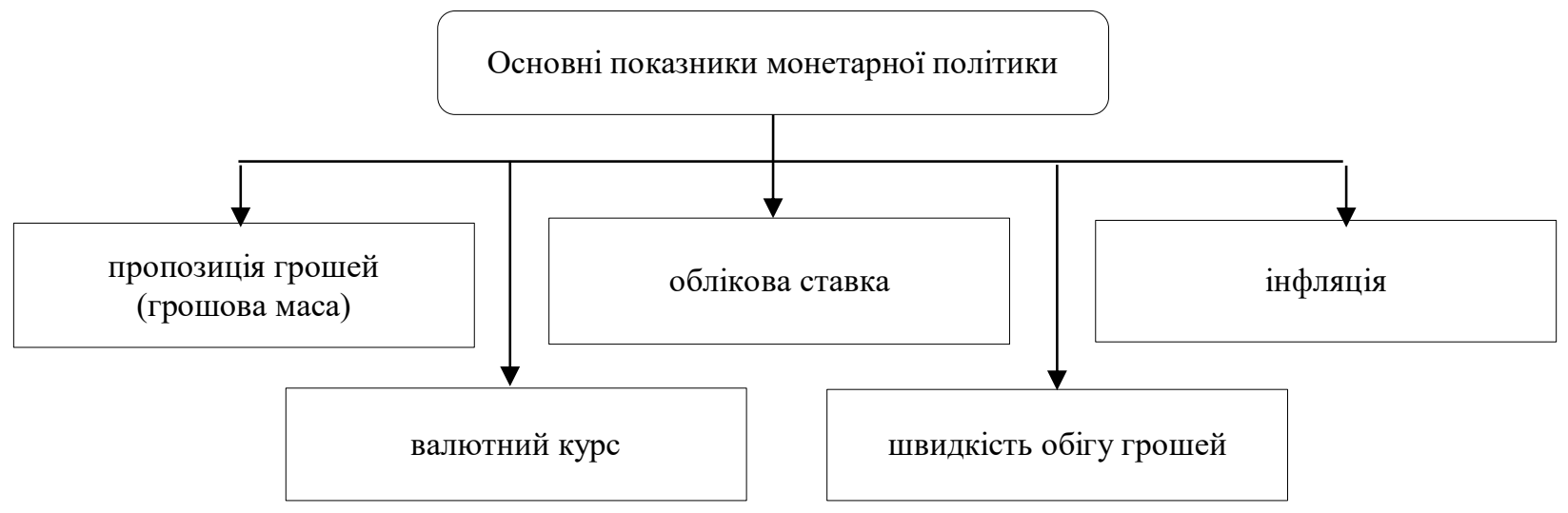

Рис. 1. Основні показники монетарної політики

Джерело: сформовано авторами на основі [5, с. 249]

Грошова маса, що перебуває в обігу, ії структура й динаміка вважаються одними з головних макроекономічних показників стану грошово-кредитного ринку.

Під грошовою масою слід розуміти всю сукупність запасів грошей у всіх їх формах, які перебувають у розпорядженні суб'єктів грошового обороту в певний момент. Склад і структуру грошової маси характеризують грошові агрегати [6, с. 162].

Грошові агрегати - зобов'язання депозитних корпорацій перед іншими секторами економіки, крім сектору загального державного управління та інших депозитних корпорацій.

В Україні Національним банком України визначено й використовується в практичній діяльності чотири грошових агрегати: M0, M1, M2 та М3. Грошовий агрегат М0 показує масу готівки, яка перебуває в обігу поза банківською системою (банкноти й монети на руках у фізичних осіб і в касах юридичних осіб). Готівкові гроші в касах банків до складу цього агрегату не входять. Грошовий агрегат М1 включає агрегат M0 і переказні депозити в національній валюті (фінансові активи, що за першою вимогою власника можуть бути обміняні на готівкові кошти за номіналом та безпосередньо використані для здійснення платежу) - це гроші, які перебувають в обігу поза банками, та 
кошти, які знаходяться на поточних рахунках у національній валюті (депозити до запитання). Грошовий агрегат М2 включає агрегат M1, переказні кошти в іноземній валюті (кошти в іноземній валюті, що за першою вимогою можуть бути обмінені на готівкові - депозити в іноземній валюті) й інші кошти (не переказні кошти до запитання, строкові кошти й кошти за іменними ощадними (депозитними) сертифікатами, емітованими банками). Грошовий агрегат М3 включає агрегат M2 й цінні папери власного боргу банків (грошові активи у вигляді банківських векселів, депозитних сертифікатів, облігацій, казначейських зобов'язань тощо, крім акцій), а також кошти клієнтів, що перебувають у довірчому управлінні банків [6, с. 163].

Пропонуємо проаналізувати динаміку зміни грошової маси в Україні за 2014-2021 роки (табл. 2).

Таблиия 2

Пропозиція грошей в Україні станом на початок 2014-2021 pp.,

млн грн

\begin{tabular}{|c|c|c|c|c|}
\hline Рік Показники & M0 & M1 & M2 & M3 \\
\hline 2014 & 282947 & 435475 & 955349 & 956728 \\
\hline 2015 & 282673 & 472217 & 993812 & 994062 \\
\hline 2016 & 314392 & 529928 & 1102391 & 1102700 \\
\hline 2017 & 332546 & 601631 & 1208557 & 1208859 \\
\hline 2018 & 363629 & 671285 & 1273772 & 1277635 \\
\hline 2019 & 384366 & 770043 & 1435221 & 1438311 \\
\hline 2020 & 470420 & 908804 & 1672122 & 1674878 \\
\hline 2021 (серпень) & 544383 & 1107513 & 1899024 & 1901286 \\
\hline Зростання, \% & 1,66 & 2,10 & 1,75 & 1,75 \\
\hline
\end{tabular}

Джерело: сформовано авторами на основі [7; 9]

Аналізуючи дані, які подано в таблиці 2, ми дійшли висновків, що протягом останніх 8 років зростання готівкової грошової маси відбулося у 1,66 рази, грошової маси за агрегатом М1 - у 2,10 рази, а решти двох агрегатів - у 1,75 рази. Тобто грошової маси побільшало у 1,75 рази (за агрегатом M3).

Пропонуємо порівняти грошові агрегати та звернути увагу на такі ключові моменти:

- по-перше, кожний наступний грошовий агрегат містить попередній, тобто збільшується на величину попереднього грошового агрегату;

- по-друге, всі грошові агрегати мають різну ліквідність (здатність до швидкого обертання), при цьому найвищу ліквідність має грошовий агрегат M0. Грошовий агрегат M1 має дещо меншу ліквідність, але також $\epsilon$ високоліквідним, оскільки грошовий обіг готівки здійснюється через банки;

- ліквідність грошового агрегату M1 значно більша у порівнянні 3 агрегатом М2, тому що елементи, пов'язані з нагромадженням, належать до складу агрегату М2;

- агрегат М3 є найменш ліквідним, оскільки для введення в обіг вимагає попереднього попередження банків, що потребує певного часу.

Наступним показником виступає облікова ставка. Облікова ставка - це 
ключова ставка процентної політики Національного банку України (далі НБУ). НБУ проводить за обліковою ставкою операції, які найбільше впливають на вартість коштів на міжбанківському ринку [9]. Це надає змогу утримувати ринкові ставки на близькому до облікової ставки рівні, тобто виконувати операційну ціль Національного банку.

Під час встановлення розміру облікової ставки, Національний банк України враховує низку економічних чинників, до яких належать: швидкість обігу грошей, валютний курс, величина попиту на цінні папери, фаза економічного циклу, інфляційні очікування, загальні прогнози розвитку економіки, політичного та соціального спрямування [10, с. 738]. Зміну облікової ставки НБУ протягом 8 років наведено на рис. 2 .

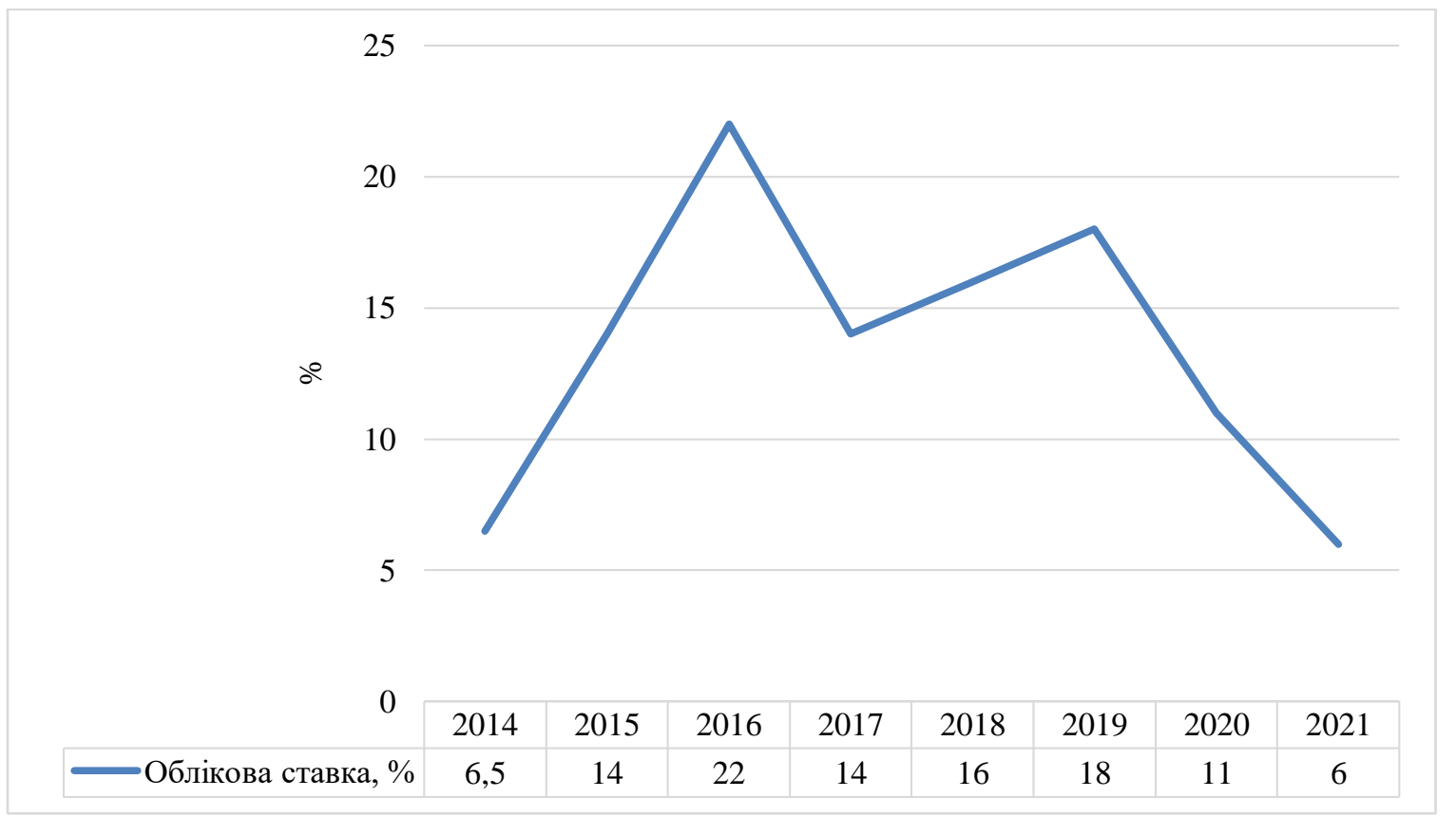

\section{Рис. 2. Динаміка облікової ставки НБУ протягом 2014-2021 рр. станом на початок кожного року, \% \\ Джерело: сформовано авторами на основі [9]}

Згідно з графіком, на початок 2021 року облікова ставка знизилась до 6\%, що є найнижчим показником в історії України. Такі дії НБУ були спрямовані для підтримки економіки країни в період поступового зниження карантинних обмежень.

Розмір облікової ставки визначається 3 дотриманням таких основних принципів [10, с. 738$]$ :

- облікова ставка використовується Національним банком одночасно як засіб реалізації грошово-кредитної політики й орієнтир ціни на гроші;

- облікова ставка $\epsilon$ одним із чинників, що характеризують основні напрями змін грошово-кредитного регулювання;

- облікова ставка $є$ найнижчою серед відсоткових ставок, за якими Національний банк може підтримати ліквідність банків.

За даними НБУ, облікова ставка лише два роки тому складала $18 \%$, а у 2021 році вона знизилась до 6\%. Отже, Національний Банк України робить 
доступним споживче кредитування, що має більшу прибутковість, водночас знижуючи вартість кредитного ресурсу. Відповідно, попит населення на купівлю споживчих товарів у кредит зросте, якщо знизити відсотки за кредитами. У такий спосіб зростатимуть і ціни, через зростання обсягів споживання товарів.

Варто зазначити, що 21 жовтня 2021 року, Правлінням Національного банку України було ухвалено рішення щодо збереження ключової ставки на рівні $8,5 \%$ річних.

Отже, варто відзначити, що облікова ставка використовується НБУ як один із основних інструментів регулювання грошового ринку. У періоди економічної нестабільності вона збільшується, а в періоди спокою зменшується. Також не слід забувати про те, що висока динаміка коливань відсоткової ставки говорить про серйозні проблеми на грошовому ринку. Зниження облікової ставки показує, що НБУ докладає чимало зусиль, щоб зробити кредитні кошти доступними для населення, що, зі свого боку, призводить до пожвавлення ділової активності в Україні.

Пріоритетною ціллю монетарної політики Національного банку $\epsilon$ підтримка цінової стабільності, тобто низьких та стабільних темпів інфляції. Цінова стабільність - це ситуація, коли ціни зростають настільки несуттєво, що громадяни не замислюються над інфляцією, ухвалюючи рішення про кредит, вкладання коштів у бізнес або заощадження [11]. Сама ж інфляція є тривалим зростанням загального рівня цін, що відображає зниження купівельної спроможності грошової одиниці. Динаміку зміни рівня інфляції в Україні подано на рис. 3.

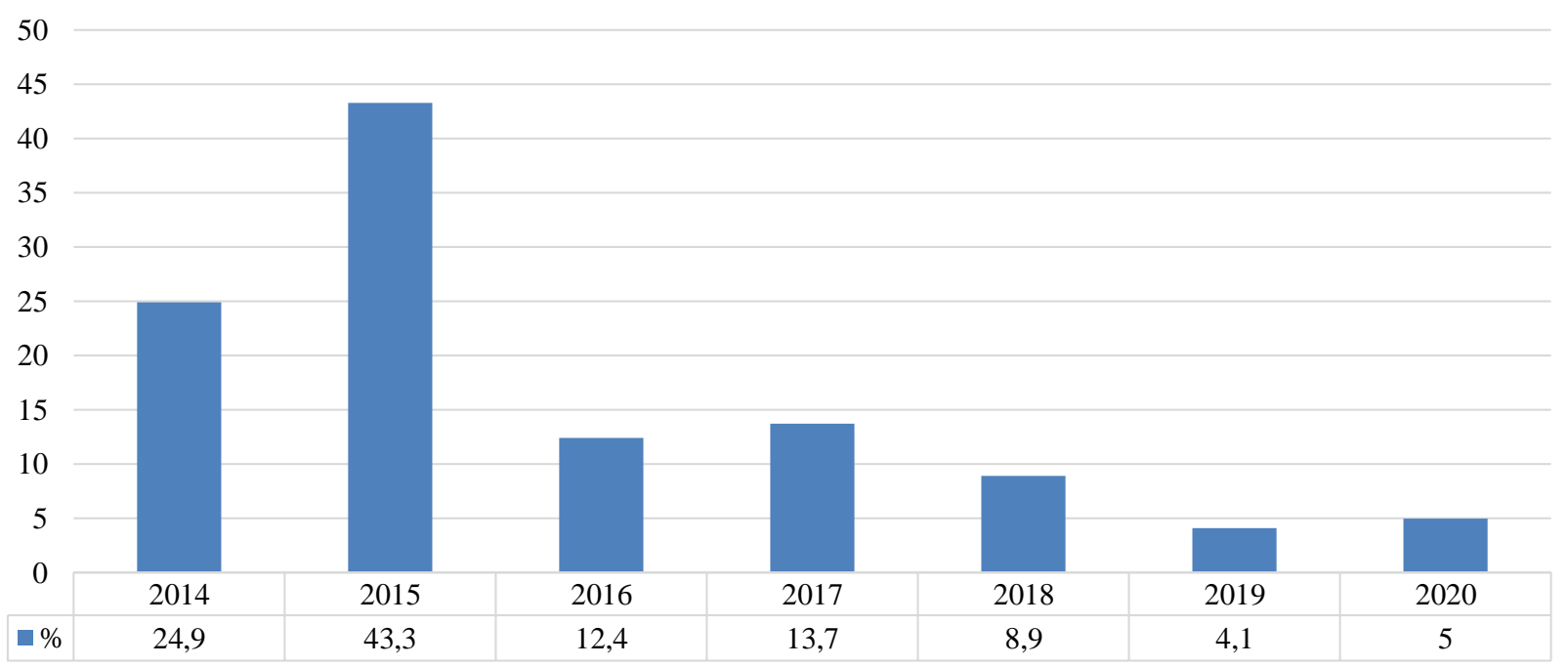

Рис. 3. Динаміка індексу інфляції в Україні за 2014-2020 рр.,\% Джерело: сформовано авторами на основі [13]

Інфляційні процеси в Україні є досить нестабільними й, відповідно до створених умов, мають порівняно великий потенціал для розвитку. Тому актуальним і до кінця не вивченим залишається питання дослідження розвитку інфляції в сучасній економіці України [12, с. 249-250].

У 2014 році відбувався стрімкий розвиток інфляційних процесів, що 
супроводжував початок економічних реформ. За підсумками року, споживчі ціни зросли на 24,9\%, а причинами цього стали:

- девальвації гривні через некоректну політику НБУ, яка проявлялася в тому, що був переоцінений обмінний курс, який виявив неготовність населення і бізнесу до таких змін, i, як наслідок, мали місце фундаментальні зрушення в економіці країни;

- нестабільна ситуація та війна на сході країни спровокували непередбачені витрати на антитерористичну операцію;

- стрімке зростання інфляційних очікувань i наростання панічних настроїв через військовий конфлікт в Україні.

У 2015 році показники перевищили не тільки аналогічні показники 2014 року, але й вперше за 10 років вийшли за межі й становили 43,3\%. Варто зазначити, що окремі економісти стверджували про галопуючу інфляцію. Основною причиною зростання інфляції аналітики називають девальвацію національної валюти, яка більшою чи меншою мірою відобразилася у зростанні цін на різні групи товарів і послуг.

У 2016 році рівень інфляції суттєво скоротився - до 12,4\%. Сповільненню інфляції та загалом інфляційного тиску сприяли помірковані фіскальна й монетарна політики, зменшення інтенсивності військового конфлікту на Сході, a також вторинні ефекти факторів із боку пропозиції сирих продуктів харчування.

У 2017 році відбулося прискорення інфляції до 13,7\%, насамперед через дію чинників, на які інструменти грошово-кредитної політики мають обмежений вплив. Зокрема, на показниках інфляції суттєво позначилося скорочення пропозиції окремих овочів і фруктів через несприятливі погодні умови в першій половині року, нестабільна ситуація у тваринництві, зростання світових цін і зовнішнього попиту на вітчизняні продукти харчування та підвищення світових цін на нафту.

Протягом 2018-2020 років інфляція поступово знизилась. Так, у 2018 році інфляція складала $-8,9 \%$, у 2019 році - 4,1\%, а у 2020 - 5\%. У вересніжовтні 2021 року інфляція досягла свого максимального значення за останні 3 роки $-10-11 \%$. На думку дослідників, надалі інфляційний тренд розвернеться. Інфляція знизиться до 9,6\% наприкінці 2021 року, а за підсумками наступного досягне цілі 5\% і надалі перебуватиме близько цього рівня, проте, до кінця 2021 року знизиться нижче 10\% та досягне цілі 5\% наприкінці 2022 року [13].

Сьогодні, інфляція - один із хворобливих і небезпечних процесів, що негативно впливає на фінанси, грошову й економічну систему загалом. Інфляція означає не тільки зниження купівельної спроможності грошей, але й підрив можливостей господарського регулювання, що зводить нанівець зусилля 3 проведення структурних перетворень, відновлення порушених пропорцій [12, с. 249].

Варто зазначити, що облікова ставка має вплив не лише на інфляцію, а й на валютний курс. Адже, чим нижчою є відсоткова ставка у країні, тим меншу підтримку має національна валюта. Особливо добре ця залежність працює в 
умовах вільного руху капіталу. Якщо існує велика різниця між відсотковими ставками, то «гарячі гроші» використовуються там, де $\epsilon$ вища ставка, й додають попиту на місцеву валюту, тобто підвищують валютно-обмінні операції [15].

Валютний курс - це ціна грошової одиниці однієї країни, виражена у грошовій одиниці іншої країни. Таке співвідношення необхідне [16, с. 165]:

- під час купівлі та продажу валюти у зв'язку з експортом й імпортом товарів чи послуг;

- для порівняння цін світових і національних ринків, а також вартісних показників різних країн, виражених у національних або іноземних валютах;

- для надання кредитів і здійснення інших зовнішньоекономічних операцій.

Протягом останніх чотирьох років спостерігається коливання валютного курсу в Україні. У таблиці 3 наведені показники, що демонструють нестабільність національної валюти.

Таблиия 3

Середній курс обміну валют (гривня до долара США) у банках України протягом 2014-2021 рр. (станом на 01.01)

\begin{tabular}{|c|c|c|}
\hline Роки & Купівля & Продаж \\
\hline 2014 & 8,2 & 8,2 \\
\hline 2015 & 16,3 & 16,5 \\
\hline 2016 & 24,5 & 25,4 \\
\hline 2017 & 26,8 & 27,5 \\
\hline 2018 & 27,7 & 28,2 \\
\hline 2019 & 27,5 & 28,2 \\
\hline 2020 & 23,6 & 24,5 \\
\hline 2021 & 28,2 & 28,5 \\
\hline
\end{tabular}

Джерело: сформовано авторами на основі [17]

Ключовим фактором, що визначає курс валюти, сьогодні, залишається пандемія COVID-19, проте, не слід забувати про інші фактори, які впливають на його значення. До них, на нашу думку, належать: стрімке відновлення економіки, грошові стимули й інфляція. Незважаючи на низку негативних факторів, українська валюта тяготить до ревальвації. 3 початку 2021 року вона зміцніла щодо долара США на 7\%. Для України, у цей складний період, велику роль відіграло рішення Міжнародного Валютного Фонду (далі - МВФ) про найбільший в історії розподіл спеціальних прав запозичення між країнамиучасницями.

Різкі коливання валюти посилюють нестабільність міжнародних економічних відносин, зокрема валютно-кредитних та фінансових, що, зі свого боку, спричиняють негативні соціально-економічні наслідки. Через збільшення курсу гривні до курсу американського долара українці втрачають значну частину своїх валютних заощаджень. Відповідно, варто приймати заходи для захисту заощаджень громадян від підвищення курсів валют щодо гривні. Для цього населенню варто зберігати свої валютні цінності в банках і страхувати їх від зниження курсів валют, а державі необхідно застосовувати валютні резерви для стабілізації валютних курсів.

До факторів, які так чи інакше впливають на валютний курс належать такі: 
1. Платіжний баланс країни. У випадку, коли торговельне сальдо країни $\epsilon$ активним, тобто надходження з-за кордону перевищують ії валютні витрати, курс національної валюти має тенденцію зростати.

2. Пропозиція грошей. Зростання у країні на 1\% грошової маси призводить до миттєвого зростання на 1\% внутрішніх цін, при цьому механізм паритету купівельної спроможності забезпечує відповідне знецінення національної валюти на $1 \%$.

3. Дефіцит державного бюджету є безпосередньою причиною збільшення грошової маси в обігу й призводить до зниження курсу національної валюти у довгостроковому періоді.

4. ВВП як основний індикатор стану національної економіки.

5. Рівень реальних відсоткових ставок визначає загальну дохідність вкладень в економіку країни.

6. Темпи інфляції. Чим вищі темпи інфляції у країні, тим нижчий курс іiі валюти, якщо не протидіють інші фактори.

7. Ступінь використання певної валюти на євроринку й у міжнародних розрахунках.

8. Ступінь розвитку фондового ринку, який $є$ конкурентом валютного ринку [16, с. 165].

Незважаючи на теоретичні напрацювання, монетарні показники не завжди вдається використати повною мірою на практиці, оскільки існують інші обставини й проблемні моменти. Окрім теорії, варто зважати на складні й неординарні умови, в яких відбувається розвиток економіки в Україні сьогодні. Це й криза державних фінансів і грошово-кредитної системи, значне послаблення фінансової стійкості й рівноваги, серйозні внутрішні й зовнішні виклики.

Через пандемію COVID-19 упродовж 2020 року макроекономічні умови були складними. Високою залишалася невизначеність щодо подальшої ситуації та впливу наслідків коронавірусу на розвиток економіки в Україні. У загальному можна зазначити, що, зважаючи на карантині обмеження та заборону значної частини економічної діяльності, відбулося скорочення доходів населення та прибутків підприємств, а також зменшення споживання населенням, припинення та призупинення інвестиційних проєктів.

Все це знаходить відображення в монетарній політиці та ії показниках. Для покращення таких показників ми рекомендуємо:

1. НБУ під час рішення про зміну облікової ставки, враховувати реальний стан економіки (якщо реальний сектор буде у фазі спаду, то збільшення облікової ставки приведе до ще більшого зростання цін і дефіциту товарів) і не зловживати таргетуванням через обмінний курс.

2. Для стримування темпів інфляції потрібно: стимулювати інвестиційну діяльність; обмежити випуск в обіг нових грошей для покриття поточного дефіциту державного бюджету; вдосконалити податкову систему; сприяти розвитку фондового ринку; запобігати недобросовісній конкуренції та монополізації.

3. Для стабілізації валютного курсу знизити боргову залежність 
(особливо перед іншими країнами й міжнародними економічними організаціями); забезпечити розвиток сприятливого інвестиційного клімату в країні; за допомогою скорочення бюджетних витрат і використання програмноцільового методу збалансувати державний бюджет.

Висновки. Зважаючи на зазначене, можна стверджувати, що монетарна політика - це сукупність взаємопов'язаних заходів у сфері грошового обігу й кредиту, яка спрямована на здійснення центральним банком своїх функцій та забезпечення платоспроможності грошово-кредитної системи. Якщо деталізувати вищевикладене, то відзначимо, що грошово-кредитна політика в Україні покликана знизити індекс споживчих цін і забезпечити стабільність національної валюти. Для досягнення цієї мети потрібно звернути увагу на такі рекомендації: стабілізація валютного курсу, ревальвація гривні, викриття тіньового сектору економіки, збільшення рівня золотовалютних резервів, зменшення обсягів зовнішнього боргу й збільшення темпів його погашення. Необхідним, на нашу думку, є зниження облікової ставки, що сприятиме здешевленню банківських кредитів і зниженню ставок за депозитами. Ми вважаємо також важливим дослідження природи інфляції у нашій країні, що дозволить проаналізувати iї сутність та знайти шляхи зниження темпів іiі зростання.

\section{Список використаної літератури:}

1. Світлична В.Ю. Визначення сутності та організаційних засад реалізації грошово-кредитної політики. Науковий вісник Ужгородського національного університету. Серія: Міжнародні економічні відносини та світове господарство. 2019. Вип. 24. Ч. 3. С. 72-77.

2. Дячек С.M., Панасюк О.О. Грошово-кредитна політика України: сутність, загрози, оцінка. Вісник Житомирського державного технологічного університету. Серія: Економічні науки. 2013. № 2 (640). С. 227-233.

3. Про Національний банк України: Закон України від 20.05.1999 р. № 29. URL: https://zakon.rada.gov.ua/laws/show/679-14/page\#Text (дата звернення: 30.10.2021).

4. Глущенко С.В. Монетарна політика: теоретико-методологічні аспекти: підруч. для студ. вищ. навч. закл. Київ: НаУКМА, 2017. 64 с.

5. Іванчук Н.В. Гроші і кредит: навч. посібник. Острог: Видавництво Національного університету «Острозька академія», 2021. 332 с.

6. Пріхно І.М., Частоколенко І.П., Марченко А.П. Напрями оптимізації обсягу і структури грошової маси в Україні. Таврійський науковий вісник. Серія: Економіка. 2020. Вип. 4. С. 161-168. DOI: https://doi.org/10.32851/27080366/2020.4.20.

7. Міжнародний валютний фонд: Економічні та фінансові показники України. URL: http://www.ukrstat.gov.ua/imf/Pokaz.html (дата звернення: 23.10.2021).

8. Омельченко O.I., Рац О.М. Аналіз та регулювання грошової маси в Україні. Ефективна економіка. 2018. № 3. URL: http://www.economy.nayka.com.ua/?op=1\&z=6176 (дата звернення: 28.10.2021).
9. Національний
банк
України:
Облікова
ставка
НБУ. 

29.10.2021).

10. Биховченко В.П., Кирильчук О.В. Облікова ставка як інструмент грошово-кредитної політики національного банку України. Глобальні та національні проблеми економіки. 2016. Вип. 10. С. 737-740.
11. Національний
банк
України:
Монетарна
політика.

URL: https://bank.gov.ua/ua/monetary (дата звернення: 29.10.2021).

12. Коваленко П.К. Інфляція в Україні. Економіко-правові та управлінські аспекти розвитку суспільства: молодіжний погляд: матеріали міжнародної науково-практичної конференції, 01.11.2019, м. Дніпро. 2019. С. 249-250.

13. Інфляційні звіти НБУ. URL: https://bank.gov.ua/ua/monetary/report (дата звернення: 29.11.2021).
14. Річний
звіт
НБУ
2014
p.

URL: https://centerforfinancialstability.org/fsr/ukr_ar_201507.pdf (дата звернення: 29.11.2021).

15. Юридична газета онлайн: Інструменти монетарної політики: що на що впливає. URL: https://yur-gazeta.com/publications/practice/bankivske-ta-finansovepravo/instrumenti-monetarnoyi-politiki-shcho-na-shcho-vplivae.html (дата звернення: 23.10.2021).

16. Михайловська I.М., Ларіонова К.Л. Гроші та кредит: практикум. Львів: Новий Світ-2000. 2020. 312 с.

17. Мінфін. Архів валютних курсів. https://index.minfin.com.ua/ua/exchange/archive/ (дата звернення: 23.10.2021).

\section{Reference:}

1. Svitlichna, V.J. (2019). Vyznachennia sutnosti ta orhanizatsiinykh zasad realizatsii hroshovo-kredytnoi polityky [Defining the essence and organizational principles of monetary policy]. Naukovyi visnyk Uzhhorodskoho natsionalnoho universytetu. Seriia: Mizhnarodni ekonomichni vidnosyny ta svitove hospodarstvo Scientific Bulletin of Uzhhorod National University. Series: International Economic Relations and the World Economy, 3 (24), $72-77$ [in Ukrainian].

2. Diachek, S.M., \& Panasiuk, O.O. (2013). Hroshovo-kredytna polityka Ukrainy: sutnist, zahrozy, otsinka [Monetary policy of Ukraine: essence, threats, assessment]. Visnyk Zhytomyrskoho derzhavnoho tekhnolohichnoho universytetu. Seriia: Ekonomichni nauky - Bulletin of Zhytomyr State Technological University. Series: Economic Sciences, 2 (640), 227-233 [in Ukrainian].

3. Pro Natsionalnyi bank Ukrainy: Zakon Ukrainy № 29 [Law of Ukraine «On the National Bank of Ukraine» № 29]. (1999, May 20). zakon.rada.gov.ua. Retrieved from: https://zakon.rada.gov.ua/laws/show/679-14/page\#Text [in Ukrainian].

4. Glushchenko, S.V. (2017). Monetarna polityka: teoretyko-metodolohichni aspekty [Monetary policy: theoretical and methodological aspects]. Kyiv: NaUKMA [in Ukrainian].

5. Ivanchuk, N.V. (2021). Hroshi i kredyt [Money and credit]. Ostrog: Ostroh Academy National University Publishing House [in Ukrainian].

6. Prikhno, I.M., Chastokolenko, I.P., \& Marchenko, A.P. (2020). Napriamy optymizatsii obsiahu i struktury hroshovoi masy v Ukraini [Directions for optimizing 
the volume and structure money supply in Ukraine]. Tavriiskyi naukovyi visnyk. Seriia: Ekonomika - Tavrian Scientific Bulletin. Series: Economics, 4, 161-168. DOI: https://doi.org/10.32851/2708-0366/2020.4.20 [in Ukrainian].

7. Mizhnarodnyi valiutnyi fond: Ekonomichni ta finansovi pokaznyky Ukrainy [International Monetary Fund Economic and financial indicators of Ukraine]. www.ukrstat.gov.ua. Retrieved from: http://www.ukrstat.gov.ua/imf/Pokaz.html [in Ukrainian].

8. Omelchenko, O.I., \& Rats, O.M. (2018). Analiz ta rehuliuvannia hroshovoi masy v Ukraini [Analysis and regulation of the money supply of Ukraine]. Efektyvna ekonomika - Effective economy, 3. Retrieved from: http://www.economy.nayka.com.ua/?op=1\&z=6176 [in Ukrainian].

9. Natsionalnyi bank Ukrainy: Oblikova stavka NBU [National Bank of Ukraine: NBU Discount Rate]. old.bank.gov.ua. Retrieved from: https://old.bank.gov.ua/control/uk/publish/article?art_id=123272 [in Ukrainian].

10. Bikhovchenko, V.P., \& Kirilchuk, O.V. (2016). Napriamy optymizatsii obsiahu i struktury hroshovoi masy v Ukraini [The discount rate as an instrument of monetary policy of the National Bank of Ukraine]. Hlobalni ta natsionalni problemy ekonomiky - Global and national economic problems, 10, 737-740 [in Ukrainian].

11. Natsionalnyi bank Ukrainy: Monetarna polityka [National Bank of Ukraine: Monetary Policy]. bank.gov.ua. Retrieved from: https://bank.gov.ua/ua/monetary/stages/archive-rish [in Ukrainian].

12. Kovalenko, P.K. (2019). Infliatsiia v Ukraini [Inflation in Ukraine]. Mizhnarodna naukovo-praktychna konferentsiia «Ekonomiko-pravovi ta upravlinski aspekty rozvytku suspilstva: molodizhnyi pohliad» - International scientific-practical conference "Economic, legal and managerial aspects of development society: youth view». (pp. 249-250). Dnipro [in Ukrainian].

13. Infliatsiini zvity NBU [NBU Inflation Reports]. bank.gov.ua. Retrieved from: https://bank.gov.ua/ua/monetary/report [in Ukrainian].

14. Richnyi zvit NBU 2014 [Annual Report of the NBU 2014]. centerforfinancialstability.org. Retrieved from: https://centerforfinancialstability.org/fsr/ukr_ar_201507.pdf [in Ukrainian].

15. Yurydychna hazeta onlain: Instrumenty monetarnoi polityky: shcho na shcho vplyvaie [Legal Newspaper Online: Monetary Policy Tools: What Affects What]. yur-gazeta.com. Retrieved from: https://yurgazeta.com/publications/practice/bankivske-ta-finansove-pravo/instrumentimonetarnoyi-politiki-shcho-na-shcho-vplivae.html [in Ukrainian].

16. Mikhailovskaya, I.M., \& Larionova, K.L. (2020). Hroshi ta kredyt [Money and credit]. Lviv: Novyi Svit-2000 [in Ukrainian].

17. Minfin. Arkhiv valiutnykh kursiv [Ministry of Finance. Exchange rate archive]. index.minfin.com.ua. Retrieved from: https://index.minfin.com.ua/ua/exchange/archive/ [in Ukrainian].

\section{Відомості про авторів:}

ПЕТИК Любов Орестівна - кандидат економічних наук, доцент кафедри фінансового менеджменту, Львівський національний університет імені Івана Франка (79000, м. Львів, вул. Медової Печери, 53, e-mail: 
liubapetyk@ukr.net).

БАЦМАН Ірина Вікторівна - студентка факультету управління фінансами та бізнесу, Львівський національний університет імені Івана Франка (79000, м. Львів, вул. Медової Печери, 53, e-mail: ira.batsman@ukr.net).

БІДА Марта Сергіївна - студентка факультету управління фінансами та бізнесу, Львівський національний університет імені Івана Франка (79000, м. Львів, вул. Медової Печери, 53, e-mail: mybonanzaluck @gmail.com).

PETYK Lyubov - Candidate of Economic Sciences, Associate Professor of the Department of Financial Management, Ivan Franko National University of Lviv (79000, Lviv, 53, Medova Pechera Str., e-mail: liubapetyk@ukr.net).

BATSMAN Iryna - Student of the Faculty of Financial Management and Business, Ivan Franko National University of Lviv (79000, Lviv, 53, Medova Pechera Str., e-mail: ira.batsman@ukr.net).

BIDA Marta - Student of the Faculty of Financial Management and Business, Ivan Franko National University of Lviv (79000, Lviv, 53, Medova Pechera Str., e-mail: mybonanzaluck@gmail.com).

ПЕТИК Любовь Орестовна - кандидат экономических наук, доцент кафедры финансового менеджмента, Львовский национальный университет имени Ивана Франка (79000, г. Львов, ул. Медовой Пещеры, 53, e-mail: liubapetyk@ukr.net).

БАЦМАН Ирина Викторовна - студентка факультета управления финансами и бизнеса, Львовский национальный университет имени Ивана Франка (79000, г. Львов, ул. Медовой Пещеры, 53, e-mail: ira.batsman@ukr.net).

БИДА Марта Сергеевна - студентка факультета управления финансами и бизнеса, Львовский национальный университет имени Ивана Франка (79000, г. Львов, ул. Медовой Пещеры, 53, e-mail: mybonanzaluck@ gmail.com).

УДК: 332.12:338.43:339.92

DOI: 10.37128/2411-4413-2021-4-8

ТОМАШУК І.В., доктор філософії з економіки, стариий викладач кафедри економіки та підприємницької діяльності

РОЗВИТОК

СІЛЬСЬКИХ

ТЕРИТОРІЙ

УКРАЇНИ В

СИСТЕМI

СВРОІНТЕГРАЦІЙНИХ ПРОЦЕСІВ
БАЛДИНЮК В.М., кандидат наук з держсавного управління, доцент кафедри адміністративного менеджсменту та альтернативних джсерел енергї, Вінницький національний аграрний університет (м. Вінниця)

ТОМАШУК І.О., аспірант Національного наукового центру "Інститут аграрної економіки" (м. Kü̈в) 